\title{
PENGARUH CITRA IMAGE (BRAND IMAGE) DAN KUALITAS TERHADAP KEPUTUSAN PEMBELIAN PADA PT. FASTFOOD INDONESIA TBK. (KFC) CABANG PEMATANGSIANTAR
}

\author{
Oleh: \\ Ade Devi Putriani \\ S1 Manajemen \\ Darwin Lie, Marisi Butarbutar, Stefi Inggrid Thressa
}

Abstraksi

Penelitian ini menggunakan penelitian lapangan dan kepustakaan. Populasi yang digunakan adalah sebanyak 58 responden yaitu warga Perumahan Karangsari Permai RT 001 Kec. Siantar Martoba Kel. Tambun Nabolon Pematangsiantar. Pengumpulan data dilakukan dengan kuesioner, wawancara, dan dokumentasi. Teknik analisa yang digunakan ialah regresi linier berganda, koefisien korelasi dan determenasi serta pengujian hipotesis dengan uji $\mathrm{t}$ dan uji $\mathrm{F}$. Kesimpulan hasil penelitian:1. Konsumen setuju dengan citra merek, kualitas produk sudah baik dan konsumen setuju dengan keputusan pembelian.2. Hasil analisis regresi $\hat{Y}=2,990+0,134 X_{1}+$ $0,467 \mathrm{X}_{2}$ artinya citra merek (brand image) dan kualitas produk berpengaruh positif terhadap keputusan pembelian pada PT. Fast Food Indonesia Tbk (KFC) Cabang Pematangsiantar. 3. Hasil analisis korelasi diperoleh nilai $\mathrm{r}=$ 0,540 artinya terdapat hubungan yang sedang dan positif antara citra merek (brand image), kualitas produk dan keputusan pembelian pada PT. Fast Food Indonesia Tbk (KFC) Cabang Pematangsiantar. Tinggi rendahnya keputusan pembelian dapat dijelaskan oleh citra merek (brand image) dan kualitas produk sebesar 54\%. 4.Hipotesis penelitian $\mathrm{H}_{0}$ ditolak, artinya citra merek (brand image) dan kualitas produk berpengaruh positif dan signifikan terhadap keputusan pembelian pada PT. Fast Food Indonesia Tbk (KFC) Cabang Pematangsiantar baik secara simultan maupun parsial.

Adapun saran dari hasil penelitian ini menyimpulkan bahwa PT. Fast Food Indonesia Tbk (KFC) Cabang Pematangsiantar untuk mempengaruhi keputusan pembelian konsumen, maka perlu adanya perbaikan, agar karyawan lebih meningkatkan pelayanan dan bersikap lebih aktif dalam mengenalkan produk terbaru KFC, harus memberikan apresiasi yang lebih agar kualitas yang diberikan menjadi maksimal, memeriksa kembali kebersihan produk, mencari informasi tentang keinginan konsumen.

Kata kunci: Citra Merek, Kualitas Produk dan Keputusan Pembelian

\section{Abstraction}

This research was conducted using library research and field research. The population used is the author of 58 respondent are resident of Karangsari Permai RT 001. Data was collected through interviews, technical questionners, and technical documentation. The analysis teqhnique used is a simple linier regression, and correlation coefficients of determination, hypotesis test $F$ and hypotesis test $t$. The result of study:1.Consumer agree with the brand image, quality of product has been good, and consumer agree with decision purchasing.2.Results of regression testing is $\hat{Y}=2,990+0,134 X_{1}+0,467 X_{2}$, means the brand image and quality of product has positive effect on purchasing decision in PT. Fast Food Indonesia Tbk (KFC) Pematangsiantar.3)The value correlation of $r=0,540$, which means there is high and positive relationship between brand image, quality of product and purchasing decision in PT. Fast Food Indonesia Tbk (KFC). The level of purchasing decision can be explained by the brand image and quality of product with 54\%. 4) Hypothesis $H_{0}$ is rejected, it means the brand image and quality of product has positive and significant influence on purchasing decision in PT. Fast Food Indonesia Tbk (KFC) Pematangsiantar.

The suggestion of the research concluded that PT. Fast Food Indonesia Tbk (KFC) Pematangsiantar in the influence purchasing decision of consumer, the need for improvement in certain dimension such, employess have to further improve service and be more active in introducing new products $\mathrm{KFC}$, provide a deeper appreciation for the quality given to maximum, checking back hygiene products, look for information about the consumer desires.

Keywords: Brand image, Quality of Product and Purchasing Decision

\section{A. PENDAhuluan}

1. Latar Belakang Masalah

PT. Fast Food Indonesia Tbk (KFC) merupakan salah satu perusahaan yang menjual makanan cepat saji atau junk food. Keputusan masyarakat untuk membeli produk-produk yang ditawarkan oleh KFC dinilai cukup baik, dari wawancara dengan dengan asisten manajer 2, omset yang dapat dicapai dari pembelian masyarakat
Pematangsiantar berjumlah sekitar Rp. 31.000.000,pada hari Senin s/d Jum'at dan Rp. 43.000.000,pada hari Sabtu, Minggu dan hari besar lainnya.

Untuk mendukung dan mempertahankan keputusan masyarakat melakukan pembelian pada PT. Fast Food Indonesia (KFC) Cab. Pematangsiantar, KFC harus berupaya mempertahankan dan menjaga brand image (citra merek) agar konsumen tidak memiliki persepsi 
bahwa merek KFC sama dengan merek pedagang kaki lima. Selain itu, untuk memaksimalkan keputusan pembelian kualitas produk juga harus diperhatikan.

Untuk menjaga kualitasnya, produk KFC harus menerapkan standar waktu dalam proses memasak dan batas waktu produk baik untuk dikonsumsi, selain itu KFC juga menempatkan produk dalam wadah atau kemasan yang higienis sehingga produk tetap aman untuk dikonsumsi. KFC harus mampu menciptakan dan mempertahankan image sebagai makanan cepat saji yang enak, halal, berkualitas, aman dengan kemasan higienis agar mampu mendapat persepsi positif dari masyarakat Indonesia. Brand image dan kualitas produk pada PT. Fast Food Indonesia Tbk, atau KFC diduga berpengaruh terhadap keputusan pembelian. Karena hingga saat ini hampir setiap hari KFC selalu ramai dikunjungi oleh masyarakat.

\section{Rumusan Masalah}

a. Bagaimana gambaran citra merek (brand image), kualitas produk dan keputusan pembelian pada PT. Fast Food Indonesia (KFC) Pematangsiantar?

b. Bagaimana pengaruh citra merek (brand image) dan kualitas produk terhadap keputusan pembelian pada PT. Fast Food Indonesia (KFC) Pematangsiantar secara simultan maupun secara parsial?

\section{Tujuan Penelitian}

a. Untuk mengetahui gambaran brand image (citra merek), kualitas produk dan keputusan pembelian pada PT. Fast Food Indonesia Tbk (KFC) Pematangsiantar.

b. Untuk mengetahui pengaruh brand image dan kualitas produk terhadap keputusan pembelian pada PT. Fast Food Indonesia (KFC) Pematangsiantar secara simultan maupun secara parsial.

\section{Metode Penelitian}

Yang menjadi objek penelitian adalah PT. Fast Food Indonesia Tbk, (KFC) Cab. Pematangsiantar di Jalan Sutomo No. 24 ABC, Kelurahan Proklamasi, Kecamatan Siantar Barat, Kota Pematangsiantar. Pupulasi penelitian adalah warga yang sudah berusia $\geq 17$ tahun atau dianggap sudah mampu mengambil keputusan dan berada di Perumahan Karangsari Permai RT 001 RW 03, Kelurahan Tambun Nabolon Kecamatan Siantar Martoba Pematangsiantar sebanyak 58 orang.

Adapun Desain penelitian yang digunakan dalam penulisan penelitian ini adalah Penelitian Kepustakaan (Library Research) dan Penelitian Lapangan (Field Research). Teknik pengumpulan data yang dilakukan penulis dalam penelitian ini adalah berupa Kuesioner, Wawancara dan Dokumentasi. Jenis data yang digunakan dalam penelitian ini adalah jenis data kualitatif dan data kuantitatif. Hasil data yang diperoleh dari lapangan akan dianalisis secara deskriptif baik bersifat kualitatif dan kuantitatif.

\section{B. LANDASAN TEORI}

1. Manajemen Pemasaran

Menurut Kotler dan Kevin (2007:16), manajemen pemasaran sebagai analisis, perencanaan, implementasi, dan pengendalian program yang dirancang untuk menciptakan, membangun, dan mempertahankan pertukaran yang menguntungkan dengan pembeli sasaran demi mencapai tujuan organisasi. Sedangkan menurut Tjiptono (2008:16), manajemen pemasaran adalah proses perencanaan dan pelaksanaan konsepsi, penentuan harga, promosi, dan distribusi barang, jasa dan gagasan untuk menciptakan kelompok sasaran untuk memenuhi tujuan pelanggan dan organisasi. Berdasarkan pendapat diatas, maka dapat disimpulkan manajemen pemasaran sebagai proses perencanaan dan pengendalian yang dirancang untuk menciptakan, membangun, dan mempertahankan pertukaran yang menguntungkan organisasi agar tujuan utama dari pemasaran dapat tercapai.

\section{Brand Image (Citra Merek)}

Menurut Kotler (2008:259), identitas adalah berbagai cara yang diarahkan perusahaan untuk mengidentifikasikan dirinya atau memposisikan produknya. Sedangkan citra (image) yaitu persepsi masyarakat terhadap perusahaan atau produknya. Sedangkan menurut Kotler dan Kevin (2007:341), citra merek memiliki elemen-elemen dasar yang sering digunakan seperti nama, logo, simbol, desain, slogan, dan kemasan. Adapun beberapa kriteria yang harus diperhatikan dalam pemilihan elemen tersebut: mudah diingat, memiliki makna, disukai, dapat diubah, dapat diadaptasi dan dapat dilindungi Berdasarkan pendapat diatas, maka dapat disimpulkan bahwa citra merek merupakan elemenelemen dasar yang sering digunakan seperti logo, simbol, desain, slogan, dan kemasan, yang tidak terlepas dari kriteria mudah diingat, memiliki makna, disukai, dapat diubah, dapat diadaptasi dan dapat dilindungi.

\section{Kualitas}

Menurut Kotler dan Gary (2007:347), kualitas produk merupakan suatu produk untuk melakukan fungsi-fungsinya. Kemampuan itu meliputi daya tahan, kehandalan, ketelitian yang dihasilkan, kemudahan dioperasikan dan diperbaiki, dan atribut lain yang berharga pada produk secara keseluruhan. Sedangkan menurut Tjiptono (2008:213), kualitas merupakan perpaduan antara sifat dan karakteristik yang menentukan sejauh mana keluaran dapat memenuhi prasyarat kebutuhan pelanggan atau menilai sampai seberapa jauh sifat dan karakteristik itu memenuhi kebutuhannya. Berdasarkan penjelasan diatas, maka dapat disimpulkan bahwa kualitas produk adalah keseluruhan barang dan jasa yang berkaitan dengan keinginan konsumen yang secara keunggulan produk sudah layak dipasarkan sesuai harapan dari 
pelanggan, kualitas produk merupakan perpaduan antara sifat dan karakteristik produk.

\section{Keputusan Pembelian}

Menurut Daft (2007:401), sebuah keputusan merupakan pemilihan yang dibuat dari sejumlah alternatif yang ada, sedangkan pengambilan keputusan merupakan proses identifikasi permasalahan dan peluang, kemudian menyelesaikannya. Sedangkan menurut Kotler dan Gary (2012:166), proses keputusan pembelian konsumen terdiri dari lima tahap yang dilakukan oleh seorang konsumen sebelum sampai pada keputusan pembelian dan selanjutnya pasca pembelian. Berdasarkan pendapat para ahli diatas, dapat disimpulkan bahwa keputusan pembelian adalah sejumlah alternatif yang ada dan merupakan suatu proses untuk mencapai keadaan yang diinginkan dengan tidak terlepas dari proses identifikasi permasalahan dan peluang.

Menurut Kotler dan Kevin (2008:235), langkah-langkah dalam proses pembelian adalah: pengenalan masalah, pencarian informasi, penilaian alternatif, keputusan pembelian, perilaku setelah membeli

\section{Hubungan Citra Merek dan Kualitas} terhadap Keputusan Pembelian

Menurut Tjiptono (2008:21), dalam mengambil keputusan konsumen mencari informasi tentang produk dan merek tertentu dan mengevaluasi seberapa baik masing-masing alternatif tersebut dapat memecahkan masalahnya, evaluasi produk atau merek akan mengarah kepada keputusan pembelian. Tjiptono (2005:46) mengemukakan bahwa nama merek berhubungan positif dengan evaluasi produk, persepsi kualitas, dan tingkat pembelian produk. Berdasarkan pendapat para ahli diatas, penulis dapat menyimpulkan bahwa brand image (citra merek) dan kualitas produk memiliki pengaruh terhadap keputusan pembelian.

\section{PEMBAHASAN}

\section{Analisa}

\section{a. Deskriptif Kualitatif}

Analisa deskriptif kualitatif dimaksudkan untuk mendapatkan gambaran atau deskripsi mengenai tanggapan dari konsumen mengenai Pengaruh Citra Merek (Brand Image) dan Kualitas Produk terhadap Keputusan Pembelian pada PT. Fast Food Indonesia Tbk (KFC) Cabang Pematangsiantar. Adapun penetapan kriteria nilai rata-rata jawaban dari responden tersebut dimasukkan kedalam kelaskelas interval dimana penentuan interval nya memakai rumus sebagai berikut:

Interval Kelas $=$ Nilai Tertinggi - Nilai Terendah

$$
\begin{aligned}
& =\frac{5-1}{5} \\
& =\frac{4}{5}
\end{aligned}
$$

Dari rumus diatas dapat diperoleh interval kelas 0,8 sehingga berlaku ketentuan kategori dengan hasil berikut:

Tabel 1

\begin{tabular}{|c|c|c|c|}
\hline \multirow[b]{2}{*}{$\begin{array}{c}\text { Nibi } \\
\text { InterrsI }\end{array}$} & \multicolumn{3}{|c|}{ Kartgani } \\
\hline & 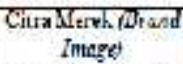 & Kualings Produh & $\begin{array}{l}\text { Keywiutzu } \\
\text { Pembellan }\end{array}$ \\
\hline $1,00-1,80$ & smast dodeseaju & sang:The Se:-1 & 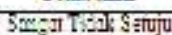 \\
\hline $1.81-2.60$ & Jute Setumu. & Thlin. 3e- & then S=luju \\
\hline$\frac{1.61-2.00}{2.61-3.10}$ & Cuknu Setupu & 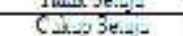 & Cukup S=luju \\
\hline $3.11-1.20$ & Sैeteju & 3 & S=luju \\
\hline $21-500$ & Suyd Setwu & Bangu. 3e. - & 3.tols=iuju \\
\hline
\end{tabular}

Nilai Interval dan Kategori Jawaban Responden.

Sumber : hasil pengolahan data

1) Gambaran Citra Merek (Brand Image) PT.

Fast Food Indonesia Tbk (KFC) Cabang Pematangsiantar.

Dari hasil analisa, dimensi keutamaan merek indikator pikiran konsumen dalam membeli makanan cepat saji memiliki nilai rata-rata 3,91 dengan kriteria jawaban setuju karena para konsumen memikirkan KFC ketika ingin membeli makanan cepat saji. Pada indikator ingatan konsumen diperoleh nilai rata-rata 3,55 dan dikategorikan setuju, karena konsumen mengingat KFC sebagai restoran cepat saji yang berkualitas.

Pada dimensi kinerja merek indikator pertama yaitu memenuhi kebutuhan konsumen memiliki nilai rata-rata 3,59 yang memiliki kriteria setuju, karena KFC memenuhi kebutuhan konsumen dalam membeli makanan cepat saji. Indikator kedua tentang sesuai dengan keinginan memiliki nilai rata-rata 3,82 dengan kriteria setuju, karena KFC menyediakan produk yang sesuai dengan keinginan konsumen.

Pada dimensi pencitraan merek indikator pertama yaitu citra pasar memiliki nilai rata-rata 3,45 dengan kriteria setuju, karena KFC memiliki citra merek yang unggul dimata konsumen. Indikator kedua tentang citra masyarakat memiliki nilai ratarata 3,59 dengan kriteria jawaban setuju, karena citra merek KFC baik dilingkungan masyarakat yang berada disekitar gerai atau restoran KFC.

Pada dimensi penilaian merek indikator pertama yaitu kredibilitas diperoleh nilai rata-rata 3,60 dengan kriteria jawaban setuju, karena KFC dianggap memiliki kredibilitas yang baik. Pada indikator kedua yaitu tentang kualitas memiliki nilai rata-rata 3,55 dengan kriteria jawaban setuju, karena KFC merupakan restoran cepat saji yang berkualitas dibandingkan restoran cepat saji yang lain.

Pada dimensi resonansi merek indikator pertama yaitu respon konsumen memiliki nilai ratarata 3,62 dengan kriteria setuju, karena membeli makanan cepat saji KFC memberikan rasa bangga pada konsumen. Pada indikator kedua yaitu tentang respon perusahaan memiliki nilai rata-rata 3,55 dengan kriteria jawaban setuju, karena KFC memberikan respon yang baik atas kepercayaan konsumen.

Pada dimensi resonansi merek indikator pertama yaitu hubungan dengan pelanggan memiliki nilai rata-rata 3,60 dengan kriteria jawaban setuju, karena KFC mempunyai dan menjalin hubungan yang baik dengan konsumen. Pada indikator kedua 
yaitu tentang komunikasi terhadap pelanggan dengan memperoleh nilai rata-rata 3,34 dengan kriteria jawaban cukup setuju, karena KFC dan konsumen sering melakukan komunikasi tentang produk terbaru KFC.

Secara keseluruhan citra merek (brand image) dengan dimensi keutamaan merek, kinerja merek, pencitraan merek, penilaian merek, perasaan merek, dan resonansi merek dinilai rata-rata 3,59. Nilai tertinggi terdapat pada dimensi keutamaan merek pada indikator pikiran konsumen memperoleh 3,91 yang berkriteria setuju. Sedangkan nilai terendah terdapat pada indikator komunikasi terhadap pelanggan memperoleh 3,34 yang berkriteria cukup setuju.

\section{2) Gambaran Kualitas produk Pada PT. Fast Food Indonesia Tbk (KFC) Cabang Pematangsiantar.}

Dari hasil analisa, dimensi performa (performance) indikator komposisi produk memiliki nilai rata-rata 3,70 dengan kriteria jawaban baik karena komposisi produk yang digunakan sudah aman untuk dikonsumsi. Pada indikator kedua yaitu tentang kualitas rasa yang sesuai memperoleh nilai rata-rata 3,64 dengan kriteria jawaban baik karena kualitas rasa yang disajikan sesuai dengan yang diinginkan konsumen.

Dimensi keistimewaan (features) indikator bahan yang digunakan memiliki nilai rata-rata 3,59 dengan kriteria jawaban baik karena bahan yang digunakan merupakan bahan unggulan. Pada indikator memperoleh nilai rata-rata 3,47 dengan kriteria jawaban baik karena produk-produk yang diberikan sudah terjamin kehalalannya.

Dimensi kehandalan (reliability) indikator jumlah porsi produk memiliki nilai rata-rata 3,67 dengan kriteria jawaban baik karena jumlah porsi yang disajikan sesuai dengan keinginan konsumen. Pada indikator kedua tentang bonus produk tertentu memperoleh nilai rata-rata 3,48 dengan kriteria jawaban baik karena KFC memberikan bonus terhadap pembelian produk tertentu.

Dimensi kesesuaian dengan spesfifikasi (conformance to spesification) indikator kemasan bawa pulang memiliki nilai rata-rata 3,67 dengan kriteria jawaban baik karena kemasan bawa pulang yang diberikan sesuai dengan kebutuhan konsumen atas produk yang dibeli. Pada indikator kedua penyajian produk bersih memperoleh nilai rata-rata 3,43 dengan kriteria jawaban cukup baik karena penyajian produk selalu dalam keadaaan bersih.

Dimensi daya tahan (durability) indikator masa taruh produk memiliki nilai rata-rata 3,47 dengan kriteria jawaban baik karena produk yang ditawarkan tahan sampai lebih dari satu hari. Pada indikator kedua suhu penyimpanan produk memperoleh nilai rata-rata 3,65 dengan kriteria jawaban baik karena produk yang ditawarkan harus dikonsumsi pada suhu tertentu.

Dimensi estetika (esthetics) indikator pertama bentuk penyajian produk memiliki nilai rata-rata 3,79 dengan kriteria jawaban baik karena bentuk penyajian produk yang ditawarkan sangat menarik. Pada indikator kedua aroma produk memperoleh rata-rata 3,72 dengan kriteria jawaban baik karena aroma dari produk yang dijual sangat menarik perhatian konsumen dan memiliki aroma yang khas.

Dimensi kemampuan pelayanan (serviceability) indikator pertama keramahan pegawai memiliki nilai rata-rata 3,63 dengan kriteria jawaban baik karena pegawai bersikap ramah kepada konsumen. Pada indikator kedua yaitu tentang kecepatan penyajian memperoleh nilai rata-rata 3,74 dengan kriteria jawaban baik karena pegawai cepat dalam menyajikan produk yang dipesan oleh konsumen.

Dimensi kualitas yang dipersepsikan (perceived quality) indikator persepsi produk sama dengan citra merek memiliki nilai rata-rata 3,50 dengan kriteria jawaban baik karena sesuai dengan citra merek yang baik menurut persepsi konsumen produk yang disajikan juga baik untuk dikonsumsi. Pada indikator kedua yaitu tentang menyediakan produk pengganti memperoleh nilai rata-rata 3,51 dengan kriteria jawaban baik karena perusahaan memberikan produk pengganti ketika terjadi kesalahan.

Secara keseluruhan, hasil dari kuesioner kualitas produk dinilai dengan rata-rata 3,60 yang berkriteria baik. Nilai tertinggi dapat dilihat pada indikator bentuk penyajian produk dengan memperoleh nilai 3,79 dengan kriteria jawaban baik. Sedangkan nilai terendah pada indikator penyajian produk selalu dalam keadaan bersih memperoleh nilai 3,43 yang berkriteria cukup baik.

3) Gambaran Keputusan Pembelian Pada PT. Fastfood Indonesia Tbk. (KFC) Cabang Pematangsiantar.

Dari hasil analisa, dimensi pengenalan masalah indikator kebutuhan primer memiliki nilai rata-rata 3,65 dengan kriteria setuju karena KFC mengetahui kebutuhan para konsumen. Pada indikator kedua kebutuhan sekunder memperoleh nilai rata-rata 3,39 dengan kriteria jawaban cukup setuju karena menu yang ditawarkan kurang memicu selera makan konsumen.

Dimensi pencarian informasi pada indikator pengalaman langsung memperoleh nilai rata-rata 3,75 dengan kriteria jawaban setuju, karena konsumen mencari informasi tentang restoran cepat saji atas kemauannya sendiri. Pada indikator kedua pengalaman keluarga memperoleh nilai rata-rata 3,52 dengan kriteria jawaban setuju karena penawaran yang diberikan oleh keluarga konsumen.

Dimensi evaluasi alternatif pada indikator pilihan lain memperoleh nilai rata-rata 3,53 dengan kriteria jawaban setuju, karena konsumen mengevaluasi restoran cepat saji kemudian melihat pilihan lain. Pada indikator kedua tentang mencari yang lain memperoleh nilai rata-rata 3,48 dengan kriteria jawaban setuju karena konsumen mengevaluasi KFC yang sesuai dengan keinginan dan tidak mencari yang lain. 
Dimensi keputusan pembelian pada indikator keyakinan konsumen memiliki nilai rata-rata 3,91 dengan kriteria jawaban setuju, karena konsumen memutuskan membeli produk yang ditawarkan karena merasa yakin dan tidak merasa ragu. Pada indikator kepercayaan memperoleh nilai rata-rata 3,79 dengan kriteria jawaban setuju, karena konsumen merasa percaya kemudian memutuskan untuk membeli.

Dimensi perilaku setelah pembelian pada indikator kepuasan konsumen memiliki nilai ratarata 3,90 dengan kriteria jawaban setuju, karena konsumen merasa puas membeli produk yang ditawarkan. Pada indikator kedua yaitu tentang rekomendasi memperoleh nilai rata-rata 3,57 dengan kriteria jawaban setuju, karena konsumen merekomendasikan teman untuk membeli produk KFC.

Secara keseluruhan keputusan pembelian dengan dimensi pengenalan masalah, pencarian informasi, evaluasi alternatif, keputusan pembelian, dan perilaku setelah pembelian dinilai rata-rata 3,65 dengan kriteria setuju. Nilai tertinggi terdapat pada indikator kebutuhan primer dengan nilai 3,91 dengan kriteria setuju. Sedangkan nilai terendah terdapat pada indikator kebutuhan sekunder dengan nilai ratarata 3,39 dengan kriteria jawaban cukup setuju.

\section{b. Deskriptif Kuantitatif}

\section{1) Regresi Linear Berganda}

Analisa regresi linier berganda digunakan untuk mengetahui pengaruh variabel bebas (X) dan variabel terikat (Y), X adalah citra merek (brand image), kualitas produk dan $\mathrm{Y}$ adalah keputusan pembelian.

Analisis dijalankan dengan melakukan tabulasi jawaban responden pada kuesioner yang telah dijalankan. Maka dilakukan perhitungan menggunakan program aplikasi SPSS untuk memperoleh nilai a dan b dengan notasi sebagai berikut: $\ddot{Y}=u+b_{1} X_{1}+b_{2} X_{2}$

Hasil Regresi Linier Berganda Coefficients $^{\mathrm{a}}$

\begin{tabular}{|c|c|c|c|}
\hline \multirow{2}{*}{ Masel } & \multicolumn{2}{|c|}{ 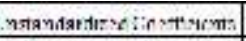 } & \multirow{2}{*}{ 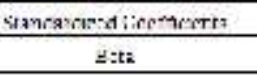 } \\
\hline & 3 & Std ETSS & \\
\hline 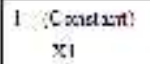 & $\begin{array}{r}2,990 \\
, 137\end{array}$ & 1,3.5. & $m$ \\
\hline$x$ & 467 & $.66=$ & $5: 8$ \\
\hline
\end{tabular}

a. Dependent Variable: Keputusan Pembelian Sumber: data primer hasil pengolahan data SPSS Versi 17

Berdasarkan hasil pengolahan data pada tabel 2 diperoleh model persamaan $\hat{Y}=2,990+0,134 X_{1}+$ $0,467 \mathrm{X}_{2}$, diartikan terdapat pengaruh positif antara variabel citra merek (brand image) $\left(\mathrm{X}_{1}\right)$ dan kualitas produk $\left(\mathrm{X}_{2}\right)$ terhadap variabel keputusan pembelian (Y) pada PT. Fast Food Indonesia Tbk (KFC) Cabang Pematangsiantar.

\section{2) Koefisien Korelasi dan Koefisien Determinasi}

Analisa distribusi frekuensi jawaban responden menurut skor dari variabel X1 (citra merek) X2 (kualitas produk) dan Y (keputusan pembelian) dimaksud sebagaimana telah dilakukan, hanyalah bermanfaat untuk memberikan informasi pendahuluani mengenai pola distribusi jawaban responden menurut skor. Selanjutnya, dilakukan perhitungan korelasi berupa derajat atau kedalaman hubungan fungsional yang menjelaskan hubungan antar perubah, dinyatakan dengan yang dinamakan koefisien korelasi yang sering disimbolkan dengan $r$, nilai $\mathrm{r}$ dapat dihitung menggunakan SPSS Versi 17. Hasil koefisien korelasi dan koefisien determinasi dapat dilihat pada tabel dibawah ini:

$$
\text { Tabel } 3
$$

Hasil Koefisien Korelasi dan Determinasi Model Summary ${ }^{\mathrm{b}}$

\begin{tabular}{|l|rr|rr|}
\hline Model & R & RSquare & ddeusted R Square & Sted. Irror of the Lsuimate \\
\hline 1 & $.735^{\circ}$ & 540 & 523 & 305025 \\
\hline
\end{tabular}

a. Predictors: (Constant), (Citra Merek) (Kualitas Produk)

b. Dependent Variable: (Keputusan Pembelian) Sumber: data primer hasil pengolahan kuesioner menggunakan SPSS Versi 17.

Dari koefisien korelasi pada tabel di atas dapat diperoleh nilai $\mathrm{r}=0,735$, yang artinya terdapat hubungan yang kuat dan positif antara citra merek (brand image), kualitas produk dan keputusan pembelian pada PT. Fast Food Indonesia Tbk (KFC) Cabang Pematangsiantar. Kemudian diperoleh nilai koefisien determinasi R Square $=0,540$, artinya tinggi rendahnya keputusan pembelian (Y) pada PT. Fast Food Indonesia Tbk (KFC) Cabang Pematangsiantar sebesar 54\% dapat dijelaskan oleh citra merek (brand image) (X1) dan kualitas produk (X2), sedangkan sisanya $46 \%$ dipengaruhi oleh faktor lain yaitu pelayanan, harga, promosi dan lainlain.

\section{3) Uji Hipotesis}

a) Uji Simultan (Uji F)

Dari hasil perhitungan koefisien korelasi diketahui bahwa Citra Merek (Brand Image) dan Keputusan Pembelian sangat berhubungan, untuk menguji kebenarannya maka dilakukan pengujian hipotesis dengan menggunakan program aplikasi SPSS Versi 17.

Dari hasil pengujian $t_{\text {hit }}$ sebesar 5,41 sedangkan $t_{\text {tab }}$ pada tingkat kepercayaan $95 \%$ adalah sebesar 2,052. Oleh karena $t_{\text {hit }}>t_{\text {tab }}$, maka Ho ditolak dan Ha diterima, artinya budaya organisasi berpengaruh positif terhadap kinerja karyawan pada PT. Taspen (Persero) cabang Pematangsiantar.

Tabel 4

Perkiraan Nilai $\mathrm{F}$ hitung ANOVA $^{\mathrm{a}}$

\begin{tabular}{|c|c|c|c|c|c|c|}
\hline \multicolumn{2}{|c|}{ Suetd } & Sin ot Serex: & Lit & Aterr Equs: & $z$ & Eg. \\
\hline \multirow{3}{*}{ ! } & 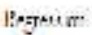 & 6n wi & : & $m \pi$ & n.,P케 & , \\
\hline & Readts & $: 14,1]$ & 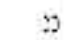 & $9,26$. & & \\
\hline & Tn: 1 & $1114,45:$ & $\therefore$ & & & \\
\hline
\end{tabular}

a. Predictors: (Constant): Citra Merek (Brand Image) dan Kualitas Produk

b. Dependent Variable: Keputusan Pembelian 


\section{b) Uji Parsial (Uji t)}

Dari hasil perhitungan koefisien korelasi diketahui bahwa Citra Merek (Brand Image), Kualitas Produk dan Keputusan Pembelian sangat berhubungan untuk menguji kebenarannya maka dilakukan pengujian hipotesis dengan menggunakan program aplikasi SPSS Versi 17.

Tabel 5

Perkiraan Nilai thitung Coefficients $^{\mathrm{a}}$

\begin{tabular}{|c|c|c|}
\hline Must & $\mathrm{t}$ & $s_{*}$ \\
\hline (Sirnitit) & tion & .421 \\
\hline 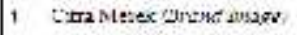 & 2,171 & , 034 \\
\hline Litatras:ectur & $8,45 y$ & ux \\
\hline
\end{tabular}

a. Dependent Variable: Keputusan Pembelian

Sumber: data primer hasil pengolahan kuesioner menggunakan SPSS Versi 17.

Berdasarkan tabel di atas diperoleh nilai thitung pada varibel $\mathrm{X}_{1}$ sebesar 2,171 dengan $\mathrm{df}=\mathrm{n}-\mathrm{k}-1(58$ 2-1=55) sebesar 1,29713, atau dengan taraf signifikan $0,034<\alpha 0,05$, maka $\mathrm{H}_{0}$ ditolak, artinya citra merek (brand image) berpengaruh positif dan signifikan terhadap keputusan pembelian pada PT. Fast Food Indonesia Tbk (KFC) Cabang Pematangsiantar. Variabel $\mathrm{X}_{2}$ sebesar 6,989 sedangkan $t_{\text {tabel }}$ dengan $\mathrm{df}=\mathrm{n}-\mathrm{k}-1, \quad(58-2-1=55)$ sebesar 1,29713, atau dengan taraf signifikansi 0,000 $<\alpha 0,05$, maka $\mathrm{H}_{0}$ ditolak, artinya kualitas produk berpengaruh positif dan signifikan terhadap keputusan pembelian pada PT. Fast Food Indonesia Tbk (KFC) Cabang Pematangsiantar secara parsial.

\section{Evaluasi}

a. Citra Merk (Brand Image) pada PT. Fast Food Indonesia Tbk. (KFC) Pematangsiantar

Hasil pengujian secara umum terhadap variabel citra merek (brand image) mempunyai pengaruh positif dan signifikan terhadap keputusan pembelian. Pada dasarnya setiap perusahaan memiliki citra dan reputasi yang berbeda. Citra merek yang nantinya akan menarik minat konsumen untuk membeli produk yang ditawarkan oleh perusahaan. Citra merek dapat terbentuk jika perusahaan mampu memperhatikan dimensi-dimensi yang berkaitan dengan citra merek seperti keutamaan merek, kinerja merek, pencitraan merek, penilaian merek, perasaan merek, dan resonansi merek. Dan ini dapat dibuktikan dari nilai rata-rata yang didapat dari pendapat responden sebesar 3,59 dengan kriteria jawaban setuju.

Namun dari nilai rata-rata 3,59 ada beberapa nilai yang masih dibawah rata-rata dari indikatorindikator lain, yang pertama indikator komunikasi terhadap pelanggan pada pernyataan PT. Fast Food Indonesia Tbk (KFC) Cab. Pematangsiantar dan konsumen sering melakukan komunikasi tentang produk terbaru KFC memperoleh nilai 3,34. Untuk mengatasi hal ini sebaiknya para karyawan harus lebih meningkatkan pelayanan dan bersikap lebih aktif dalam mengenalkan produk terbaru KFC.

Untuk indikator ingatan konsumen pada pernyataan anda mengingat KFC Cab. Pematangsiantar sebagai restoran cepat saji yang berkualitas memperoleh nilai 3,55. Hal ini dikarenakan masyarakat belum sepenuhnya mendapat kualitas terbaik dari KFC, dan cara mengatasi nya KFC harus lebih meningkatkan kualitas yang baik agar masyarakat memikirkan KFC sebagai makanan cepat saji yang berkualitas. Pernyataan KFC adalah restoran cepat saji yang berkualitas dibandingkan restoran cepat saji yang lain memperoleh nilai 3,55. Walaupun KFC telah melakukan yang terbaik dalam meningkatkan kualitas namun nilai yang diperoleh masih jauh dari rata-rata keseluruhan indikator, dan cara mengatasinya yaitu PT. Fast Food Indonesia Tbk (KFC) harus memberikan apresiasi yang lebih agar kualitas yang diberikan menjadi maksimal.

Untuk indikator citra masyarakat pada pernyataan KFC baik dilingkungan masyarakat memperoleh nilai 3,45. Cara mengatasinya adalah ikut berpartisipasi dalam kegiatan masyarakat seperti menjaga lingkungan sekitar dengan tidak membuang limbah atau sampah sembarangan. Dan ikut serta dalam kegiatan masyarakat setempat seperti gotong royong dan lain sebagainya. Pada pernyataan KFC memberikan respon yang baik atas kepercayaan konsumen memperoleh nilai 3,55. Dan cara mengatasi nya yaitu KFC harus lebih baik dalam memberikan respon terhadap konsumen yang sudah percaya membeli dan mengkonsumsi produk-produk yang ditawarkan KFC.

Dari evaluasi diatas dapat diambil kesimpulan jika semua hal-hal diatas sudah dinyatakan dengan baik, dengan memperbaiki kekurangan dari perusahaan maka konsumen tidak akan ragu dengan kualitas produk yang ditawarkan, yang sesuai dengan citra merek (brand image) yang positif, sehingga dapat terus meningkatkan penjualan produk-produk KFC sehingga KFC dapat terus berkembang menjadi restoran cepat saji yang unggul.

\section{b. Kualitas Produk pada PT. Fast Food Indonesia Tbk. (KFC) Pematangsiantar}

Hasil pengujian secara umum terhadap variabel kualitas produk mempunyai pengaruh positif dan signifikan terhadap keputusan pembelian. Kualitas produk dapat diciptakan dan dipertahankan jika perusahaan mampu memperhatikan dimensidimensi yang berkaitan dengan kualitas produk seperti performa, keistimewaan, kehandalan, kesesuaian dengan spesifikasi, daya tahan, estetika, kemampuan pelayanan, kualitas yang dipersepsikan. Dan ini dapat dibuktikan dari nilai rata-rata yang didapat dari pendapat responden sebesar 3,60 dengan kriteria jawaban setuju.

Namun dari nilai rata-rata 3,60 masih ada beberapa indikator yang memiliki nilai dibawah total nilai rata-rata, yang pertama indikator penyajian produk dalam keadaan bersih pada pernyataan penyajiaan produk KFC selalu dalam keadaan bersih memperoleh nilai rata-rata 3,43, karena KFC tidak sepenuhnya menjaga kebersihan produk-produk yang ditawarkan. Cara mengatasinya yaitu memeriksa kembali kebersihan produk yang akan disajikan kepada konsumen. Pernyataan produk-produk KFC 
sudah terjamin kehalalannya memperoleh nilai ratarata 3,47 , karena konsumen masih meragukan kehalalan produk yang ditawarkan, padahal saat ini KFC telah memiliki sertifikat halal MUI yang dipajang di dinding restoran. Hal ini dilakukan untuk membuktikan kehalalan KFC.

Untuk indikator masa taruh produk dengan pernyataan produk KFC tahan lebih dari satu hari memperoleh nilai rata-rata 3,47, karena produk tidak tahan lebih dari satu hari, dengan tempo beberapa jam produk dapat berubah rasa dan kegurihan nya sehingga konsumen tidak bisa menyimpan produk lebih lama. Dan cara mengatasinya yaitu terus mengembangkan produk agar tahan lebih dari satu hari. Pernyataan KFC memberikan bonus terhadap produk tertentu memperoleh nilai rata-rata 3,4 , karena kurang memberikan perhatian terhadap konsumen dengan memberikan bonus terhadap produk-produk tertentu. Cara mengatasinya mulai menjalin hubungan yang baik dengan konsumen dengan memberikan bonus-bonus yang menarik kepada konsumen terhadap pembelian produkproduk tertentu.

Dari pernyataan diatas dapat disimpulkan jika perusahaan memperbaiki kekurangan-kekurangan seperti yang dijelaskan pada indikator diatas maka hal ini diharapkan dapat meningkatkan kualitas produk yang ditawarkan sehingga dapat meningkatkan penjualan produk.

\section{c. Keputusan Pembelian pada PT. Fast Food Indonesia Tbk. (KFC) Pematangsiantar}

Hasil pengujian secara umum terhadap variabel keputusan pembelian dipengaruhi oleh citra merek (brand image) dan kualitas produk yang memiliki dampak positif dan signifikan. Keputusan pembelian dapat terjadi jika perusahaan mampu memperhatikan dimensi-dimensi yang berkaitan dengan keputusan pembelian seperti pengenalan masalah, pencarian informasi, evaluasi alternatif, keputusan pembelian dan perilaku setelah pembelian. Dan ini dapat dibuktikan dari nilai rata-rata yang didapat dari pendapat responden sebesar 3,65 dengan kriteria jawaban setuju.

Namun dari nilai rata-rata 3,65 masih ada beberapa indikator yang berada dibawah total nilai rata-rata, yang pertama indikator kebutuhan sekunder dengan pernyataan membeli produk karena menu yang ditawarkan memicu selera makan memperoleh nilai rata-rata 3,39, karena konsumen kurang tertarik dengan menu yang ditawarkan. Dan cara mengatasinya menciptakan menu-menu yang lebih menarik minat konsumen. Pernyataan mengevaluasi dan tidak sesuai kemudian mencari yang lain memperoleh nilai rata-rata 3,48, karena meski tidak sesuai konsumen tetap memutuskan untuk membeli. Dan cara mengatasinya mencari informasi mengenai apa yang sesuai dengan keinginan konsumen.

Untuk indikator pengalaman keluarga dengan pernyataan mencari informasi mengenai KFC atas penawaran keluarga memperoleh nilai rata-rata 3,52, karena konsumen mencari informasi atas dasar keinginan sendiri bukan penawaran atau pengalaman keluarga. Pada pernyataan akan merekomendasikan kepada teman karena cara tanggap mengatasi keluhan yang terjadi memperoleh nilai rata-rata 3,57, karena karyawan masih kurang tanggap menghadap keluhan konsumen. Dan cara mengatasinya setiap karyawan harus mampu menghadapi dan cepat tanggap dalam menyelesaikan masalah atau keluhan konsumen.

Dari pernyataan diatas dapat disimpulkan bahwa masih ada beberapa indikator yang rendah, dan perusahaan atau KFC perlu memperbaiki kekurangan-kekurangan yang ada agar perusahaan dapat terus berkembang ditandai dengan meningkatnya keputusan pembelian yang dilakukan konsumen terhadap produk-produk yang ditawarkan.

\section{KESIMPULAN DAN SARAN}

\section{Kesimpulan}

a. Hasil analisis deskriptif kualitatif citra merek (brand image) pada PT. Fast Food Indonesia Tbk (KFC) Cabang Pematangsiantar berada pada nilai 3,59 yang berkriteria setuju. Indikator nilai tertinggi pada indikator memikirkan KFC ketika akan membeli makanan cepat saji yang bernilai rata-rata 3,91. Selanjutnya, masih terdapat kelemahan pada indikator KFC sering melakukan komunikasi tentang produk terbaru pada nilai rata-rata 3,34 yang berkriteria cukup baik.

b. Hasil analisis deskriptif kualitatif tentang kualitas produk pada PT. Fast Food Indonesia Tbk (KFC) Cabang Pematangsiantar memperoleh nilai ratarata 3,60 yang berkriteria baik. Indikator nilai tertinggi pada indikator komposisi produk sudah aman untuk dikonsumsi yang bernilai rata-rata 3,91. Selanjutnya, masih terdapat kelemahan pada indikator aroma dari produk yang dijual menarik perhatian memperoleh nilai rata-rata 3,34 yang berkriteria jawaban cukup baik.

c. Hasil analisis deskriptif kualitatif keputusan pembelian pada PT. Fast Food Indonesia Tbk (KFC) Cabang Pematangsiantar berada pada nilai rata-rata 3,65 yang berkriteria setuju. Nilai ratarata tertinggi berada pada indikator percaya pada produk KFC dengan nilai rata-rata 3,91 yang berkriteria baik. Selanjutnya untuk kelemahan pada indikator menu yang ditawarkan memicu selera makan memperoleh nilai rata-rata 3,39 yang berkriteria cukup setuju.

d. Hasil analisis regresi yang diperoleh persamaan $\hat{Y}=2,990+0,134 X_{1}+0,467 X_{2}$, artinya terdapat pengaruh positif antara variabel citra merek (brand image) $\left(\mathrm{X}_{1}\right)$ dan kualitas produk $\left(\mathrm{X}_{2}\right)$ terhadap variabel keputusan pembelian (Y) pada PT. Fast Food Indonesia Tbk (KFC) Cabang Pematangsiantar. Dimana semakin baik citra merek (brand image) yang diciptakan dan kualitas produk yang diberikan semakin tinggi keputusan pembelian yang dilakukan oleh konsumen.

e. Hasil analisis korelasi yang diperoleh yaitu $\mathrm{r}=$ 0,735 menunjukkan bahwa terdapat hubungan yang kuat dan positif antara citra merek (brand image), kualitas produk dan keputusan pembelian 
pada PT. Fast Food Indonesia Tbk (KFC) Cabang Pematangsiantar. Kemudian diperoleh nilai koefisien determinasi R Square $=0,540$, artinya tinggi rendahnya keputusan pembelian (Y) pada PT. Fast Food Indonesia Tbk (KFC) Cabang Pematangsiantar sebesar 54\% dapat dijelaskan oleh citra merek (brand image) (X1) dan kualitas produk (X2), sedangkan sisanya $46 \%$ dipengaruhi oleh faktor lain yaitu pelayanan, harga, promosi dan lain - lain.

f. Hasil hipotesis dengan uji simultan diperoleh nilai $F_{\text {hitung }}$ sebesar 32,250 sedangkan $F_{\text {tabel }}$ dengan $(0,05 ; 2$ vs 55$)$ sebesar 3,16 , dengan taraf signifikansi $0,000<\alpha 0,05$ maka $\mathrm{H}_{0}$ ditolak, artinya citra merek (brand image) dan kualitas produk berpengaruh positif dan signifikan terhadap keputusan pembelian pada PT. Fast Food Indonesia Tbk (KFC) Cabang Pematangsiantar secara simultan.

g. Hasil hipotesis dengan uji parsial diperoleh nilai $t_{\text {hitung }}$ pada varibel $X_{1}$ (citra merek) sebesar 2,171 sedangkan $\mathrm{t}_{\mathrm{tabel}}$ dengan $\mathrm{df}=\mathrm{n}-\mathrm{k}-1 \quad(58-2-1=55)$ sebesar 1,29713, dengan taraf signifikan 0,034< $\alpha$ 0,05, maka $\mathrm{H}_{0}$ ditolak, artinya citra merek (brand image) berpengaruh positif dan signifikan terhadap keputusan pembelian pada PT. Fast Food Indonesia Tbk (KFC) Cabang Pematangsiantar. Variabel $\mathrm{X}_{2}$ (kualitas produk) $\mathrm{t}_{\text {hitung }}$ sebesar 6,989 sedangkan $\mathrm{t}_{\text {tabel }}$ dengan $\mathrm{df}=\mathrm{n}$ $\mathrm{k}-1,(58-2-1=55)$ sebesar 1,29713, dengan taraf signifikansi $0,000<\alpha 0,05$, maka H0 ditolak, artinya kualitas produk berpengaruh positif dan signifikan terhadap keputusan pembelian pada PT. Fast Food Indonesia Tbk (KFC) Cabang Pematangsiantar secara parsial.

\section{Saran}

a. Agar PT. Fast Food Indonesia Tbk (KFC) Cabang Pematangsiantar dapat memperbaiki citra perusahaan dengan lebih baik lagi maka perlu dilakukan perbaikan dan pengembangan citra perusahaan yang unggul melalui jalinan hubungan yang baik dengan konsumen, para karyawan harus lebih meningkatkan pelayanan dan bersikap lebih aktif dalam mengenalkan produk terbaru KFC. Memberikan respon yang baik terhadap konsumen yang sudah percaya membeli dan mengkonsumsi produk-produk yang ditawarkan KFC. Dan ikut berpartisipasi dalam kegiatan masyarakat seperti menjaga lingkungan sekitar dengan tidak membuang limbah atau sampah sembarangan. Hal ini dimaksudkan agar citra restoran cepat saji yang berkualitas dapat diciptakan dan dipertahankan dibandingkan dengan restoran cepat saji lain sehingga perusahaan mendapatkan persepsi positif dari masyarakat.

b. Agar kualitas produk tidak diragukan lagi oleh konsumen, perusahaan perlu melakukan beberapa perubahaan yang akan memberi dampak positif bagi perusahaan yaitu memeriksa kembali kebersihan produk yang akan disajikan kepada konsumen, mengembangkan produk tambahan seperti menyediakan salad buah dan sayur organik, mulai menjalin hubungan yang baik dengan konsumen dengan memberikan bonusbonus seperti memberikan mug cantik bagi konsumen yang membeli produk tertentu, atau memberikan voucher makan gratis dan lain-lain. Hal ini dilakukan agar masyarakat khususnya konsumen tidak meragukan produk-produk yang ditawarkan oleh PT. Fast Food Indonesia Tbk (KFC) Cabang Pematangsiantar.

c. Agar keputusan pembelian di PT. Fast Food Indonesia Tbk (KFC) Cabang Pematangsiantar dapat terus ditingkatkan maka perlu dilakukan perbaikan yang terus dilakukan yaitu dengan menciptakan menu-menu yang lebih menarik minat konsumen misalnya menyediakan menu paket yang lebih murah, mencari informasi mengenai apa yang sesuai dengan keinginan konsumen misalnya menyediakan produk ayam tanpa tulang dengan crispi yang lebih banyak, dan setiap karyawan harus mampu menghadapi dan cepat tanggap dalam menyelesaikan masalah atau keluhan konsumen. Hal ini dilakukan agar semakin meningkatnya minat masyarakat untuk memutuskan membeli produk KFC serta masyarakat merekomendasikan KFC kepada teman-temannya, sehingga kedepannya PT. Fast Food Indonesia Tbk (KFC) Cabang Pematangsiantar dapat lebih berkembang dan kualitas produk sesuai dengan harapan masyarakat.

d. Sehubungan dengan keterbatasan-keterbatasan yang ada pada penulis, penelitian ini masih terdapat kelemahan-kelemahan dan belum dapat mengungkap seluruh variabel yang dapat mempengaruhi citra merek (brand image), kualitas produk dan keputusan pembelian pada PT. Fast Food Indonesia Tbk (KFC) Cabang Pematangsiantar.

\section{E. DAFTAR PUSTAKA}

Daft. Richard L. 2007. Manajemen. Edisi Keenam. Jilid 1. Jakarta : Penerbit Salemba Empat.

Kotler. Philip. 2008, Manajemen Pemasaran 2. Edisi Milenium, Jakarta: PT Ikrar Mandiri.

Kotler. Philip dan Gary. Amstrong 2007. DasarDasar Pemasaran. Edisi Kesembilan. Jilid 1. Edisi Bahasa Indonesia. Jakarta: PT. Indeks. 2012. Prinsip-Prinsip Pemasaran. Edisi Ketiga belas. Jilid 1. Jakarta : Erlangga

Kotler. Philip dan Kevin Lane. Keller. 2007. Manajemen Pemasaran. Edisi Kedua belas. Jilid 1. Jakarta : PT. Indeks.

, 2008, Manajemen Pemasaran. Edisi Ketiga belas. Jilid 1. Jakarta : PT. Indeks.

Tjiptono. Fandy. 2005. Brand Management dan Strategy.Yogyakarta: Andy. 2008, Manajemen Pemasaran. Edisi ketiga. Jilid 2. Jakarta: Andy 